Acta Haematol 1991;86:I-IV

\title{
Contents, Vol. 86, 1991
}

No. 1

Original Paper

Incidence of Lymphoid Markers in Acute Myeloid Leukemia.

Alkaline Phosphatase-Antialkaline Phosphatase versus Im-

munofluorescence

Longo, R.; Vecchi, A.; Messora, C; Sacchi, S 1

Ethanol-Induced Growth Inhibition of Erythroleukemia Stem

Cells. Cell Cycle Effects

Cook, R.T.; Keiner, J.A

6

Relationship between Chromosomal Breakpoint and Molecular Rearrangement of T-Cell Antigen

Receptors in Adult T-Cell Leukaemia

Sadamori, N; Isobe, M.; Shimizu, S.; Yamamori, T.; Ito-

yama, T.; Ikeda, S.; Yamada, Y.; Ichimaru, M 14

Detection of Aggregated Leukocytes in the Circulating Pool

during Stress - Demargination Is Not Necessarily a Result

of Decreased Leukocyte Adhesiveness

Arber, N.; Berliner, S.; Rotenberg, Z.; Friedman, J.; Bela-

godatni, E.; Ostfeld, L; Aronson, M.; Pinkhas, J 20

Analysis of Idiopathic Thrombocytopenic Purpura Patients with Antiglycoprotein $\Pi \mathrm{lb} / \mathrm{IIIa}$ or $\mathrm{lb}$

Autoantibodies Nomura, S.; Yanabu, M.; Soga, T.; Kido, H.; Fukuroi, T.; Yamaguchi, K.; Nagata,

H.; Kokawa, T.; Yasunaga, K. . 25

Serum B2-Microglobulin in Patients with Adult T-Cell Leu

kemia

Tsuda, H.; Ishii, T.; Sawada, T.; Takatsuki, K

Detection of Granulocyte-Macrophage Colony-Stimulating Factor in Cerebrospinal Fluid of

Patients with Aseptic Meningitis

Shimoda, K.; Okamura, S.; Omori, F.; Mizuno, Y.; Hara,

T.; Aoki, T.; Akeda, H.; Ueda, K.; Niho, Y 36

Case Reports

An Unusual Case of Amyloidosis Complicating Light Chain

Myeloma

Handa, S.I.; Sheehan, T.; Ludlam, C.A

Acute Eosinophilic Leukemia in a Patient with Preexistent

Myelodysplastic Syndrome

Murakawa, M.; Shibuya, T.; Taniguchi, S.; Nakashima, K.;

Okamura, T.; Harada, M.; Niho, Y 42

Recombinant Human Erythropoietin Induced Rapid Healing

of a Chronic Leg Ulcer in a Patient with Sickle Cell Disease

Al-Momen, A.-K.M 46

Megakaryocytic Phagocytosis in a Chromosomally Normal

Neonate with Transient Myeloproliferative Disorder

Lam, T.K.; Prematilleke, M.N.; Li, C.K.; Fok, T.F. ... 49 
Correspondence

Frequency of HLA-A,B and DR Antigens in Patients with

Polycythemia vera

Stavropoulos, C; Petropoulou, F.; Christophoraki, M.;

Theodosoudi, E.; Kandidaki, E.; Papanickolaou, M.;

Mavrikakis, M.; Gyftaki, H 51

A Case of Lymphoblastic Lymphoma with Pre-B Cell Pheno-

type

Nakamura, N.; Tominaga, K.; Abe, M.; Wakasa, H. . . 53 Production of Dysplastic Platelets in Chronic Myeloproliferative Diseases

Woods, M.; Trowbridge, T 55

Recurrent Bilateral Parotitis in Acute Myeloid Leukemia

Shpilberg, O.; Ra'anani, P.; Ben-Bassat, I.; Ramot, B. . 56

No. 2

Mini Review

Pathophysiology of Aplastic Anaemia

Nissen, C 57

Original Paper

Chronic Childhood Neutropenia: Studies on the in vitro Clono-

genicity of Bone Marrow Myeloid Progenitors

Pistoia, V.; Corcione, A.; Pasino, M.; Roncella, S.; Fava-

reto, F.; Micalizzi, C; Ferrarini, M.; Mori, P.G 61

In vivo Effect of Human Granulocyte Colony-Stimulating Fac

tor Derivatives on Hematopoiesis in Primates

Kato, Y.; Yamamoto, M.; Ikenaga, T.; Shintome, T.; Asano,

M.; Okabe, M.; Hara, T.; Deguchi, T 70

Biochemical and Molecular Characterization of Variant Pyru-vate Kinase Enzymes and Genes

from Three Patients with Red Blood Cell Pyruvate Kinase Deficiency Johnson, M.L.; Jones, D.P.;

Freeman, J.M.; Wang, W. . 79

Bone Marrow Cell Populations Mimicking Common Acute Lymphoblastic Leukemia in Infants

with Stage IV-S Neu-roblastoma

Mandel, M.; Rechavi, G.; Neumann, Y.; Biniaminov, M.;

Brok-Simoni, F.; Bojanover, Y.; Burstein, Y.; Ben-Bassat,

I.; Ramot, B 86

Clinical Significance of Endothelial Damage Markers in Essential Mixed Cryoglobulinemia

Toschi, V.; Fiorini, G.F.; Motta, A.; Renoldi, P.; Parac-

chini, M.L.; Gibelli, A 90

IV

Contents

Case Reports

Human Recombinant Granulocyte Colony-Stimulating Factor

for the Treatment of Autoimmune Neutropenia

Takahashi, K.; Taniguchi, S.; Akashi, K.; Fujimoto, K.;

Sibuya, T.; Ishibashi, H.; Harada, M.; Niho, Y 95

First Report of Centroblastic Lymphoma in a Human Immu

nodeficiency Virus-Positive Patient with a Rare Congenital

Coagulation Disorder (Factor X Friuli)

Luzzatto, G.; Galligioni, A.; Pennelli, N.; Doro, D.; Giro-

lami, A 99 
Acquired Cyclic Haematopoiesis Associated with a Radiation-Induced Chromosomal

Abnormality with Clonal, Morphologically Normal Circulating Leucocytes Crown, J.P.; Jhanwar,

S.; Haimi, J.; Andreef, M.; Gee, T. 103

A Case of Lymphoma-Type Alpha-Chain Disease

Itoh, Y.; Ohtaki, H.; Ono, T.; Mori, N.; Kawaoi, A.; Kawai, T. 107

Short Communication

Two Additional Cases of Isochromosome 21q or Transloca-

tion 21 q21 q in Hematological Malignancies

Huret, J.L.; Schoenwald, M.; Gabarre, J.; Vaugier, G.L.;

Tanzer, J 111

Correspondences

Thymopentin in the Treatment of Myelodysplastic Syndromes

Latagliata, R.; Petti, M.C.; Aloe Spiriti, M.A.; Tirindelli,

M.C.; Fazi, P.; De Gregoris, C; Mandelli, F 115

Fetal Red Cell in Thai Thalassemia Trait Patients

Chiewsilp, A.; Fucharoen, S.; Apibal, S.; Soponsuksatit, A. 116

No. 3

Haematopoietic Growth Factors: Biology and Clinical Use

Introduction

Polli, E.E 121

In vitro Biological Activities of the Haemopoietic Growth Factors: Implications for Their Clinical Use

Testa, N.G 122

Hematopoietic Growth Factors: Interactions and Regulation

of Production

Brach, M.A.; Herrmann, F 128

Clinical Role of Colony Stimulating Factors

Brugger, W.; Rosenthal, F.M.; Kanz, L.; Mertelsmann, R. 138 The Role of Interleukin-1 in

Hematopoiesis

Fibbe, W.E.; Willemze, R 148

The Role of Haematopoietic Growth Factors in Bone Marrow

Transplantation

Polli, E.E 155

Erythropoietin: Clinical Applications

Foa, P 162

No. 4

Original Paper

Effect of Benzene on Fibroblastoid Colony-Forming Units in

Mice

Ingendaay, A.; Seidel, H.J 169

Molecular Basis of Beta-Thalassemia intermedia in a Southern Italian Region (Puglia)

Leoni, G.B.; Rosatelli, C; Vitucci, A.; Addis, M.; Loi, A.;

Tannoia, N.; Cao, A 174

Definition of the Mutations of G6PD Wayne, G6PD Viang-

chan, G6PD Jammu, and G6PD 'LeJeune'

Beutler, E.; Westwood, B.; Kuhl, W 179

Changes in $\mathrm{Cu}, \mathrm{Zn}$-Superoxide Dismutase Gene during In

duced Erythroid and Myeloid Differentiation

Tomoda, T.; Nomura, I.; Kurashige, T.; Kubonishi, I.;

Miyoshi, I.; Sukenaga, Y.; Taniguchi, T 
Comparison of Hemin Enhancement of Burst-Forming Units-Erythroid Clonal Efficiency by Progenitor Cells from Normal and HIV-Infected Patients

Abraham, N.G.; Mathew, A.; Jiang, S.; Lutton, J.D.; Nishi-

mura, M.; Chertkov, J.L.; Levere, R.D

Occurrence of Hereditary Leaky Red Cell Syndrome and Partial Coagulation Factor VII

Deficiency in a Spanish Family

Vives Corrons, J.LL; Besson, I.; Merino, A.; Monteagudo,

J.; Reverter, J.C.; Aguilar, J.LI.; Enrich, C 194

Case Reports

Cyclosporin in Steroid-Resistant Auto-Immune Haemolytic

Anaemia

Dündar, S.; Özdemir, O.; Özcebe, 0200

Disseminated Intravascular Coagulation in a Patient with Pro

gressive Systemic Sclerosis Associated with Necrotizing

Angiitis and Generalized Lymphadenopathy

Kamouchi, M.; Yoshinari, M.; Goto, H.; Ishitsuka, T.;

Murai, K; Tashiro, K; Fujishima, M 203

Gamma-Melanocyte-Stimulating Hormone-Like Immunore-activity in Blood Cells of Human

Eosinophilic Patients Johansson, O.; Virtanen, M.; Hilliges, M.; Hansson, L.-O. 206

Lymphocytic Clusters in Peripheral Blood: An Atypical Mor

phologic Pattern of Chronic Lymphocytic Leukemia

Bizzaro, N.; Piazza, 1209

Phenytoin-Induced Agranulocytosis: A Nonimmunologic Idiosyncratic Reaction? Sharafuddin, M.J.A.; Spanheimer, R.G.; McClune, G.L. 212

Successful Treatment of Hemosiderosis with Regular Phlebotomy and Recombinant Human

Erythropoietin. Case Report and Ferrokinetic Studies Hotta, T.; Inoue, C; Tsushita, K; Miura, Y.;

Saito, H. . 214

Author Index 217

Subject Index 219 